\title{
Contested Grounds: Fieldwork Collaborations with Artists in Corrientes, Argentina
}

Arnd Schneider

\section{(2) OpenEdition}

\section{Journals}

Electronic version

URL: http://journals.openedition.org/actesbranly/431

DOI: 10.4000/actesbranly.431

ISSN: 2105-2735

Publisher

Musée du quai Branly Jacques Chirac

\section{Electronic reference}

Arnd Schneider, "Contested Grounds: Fieldwork Collaborations with Artists in Corrientes, Argentina », Les actes de colloques du musée du quai Branly Jacques Chirac [Online], 2 | 2009, Online since 18 May 2010, connection on 08 September 2020. URL : http://journals.openedition.org/actesbranly/431 ; DOI : https://doi.org/10.4000/actesbranly.431

This text was automatically generated on 8 September 2020

(C) Tous droits réservés 


\title{
Contested Grounds: Fieldwork Collaborations with Artists in Corrientes, Argentina ${ }^{1}$
}

\author{
Arnd Schneider
}

1 This essay is an exercise in dialogical anthropology which fathoms for the present those 'speaking terms' which James Clifford (1988:126) found characteristic of art anthropology encounters in France in the 1920s and 1930s, epitomized by the interdisciplinary, surrealist journal Documents. Since the early 1990s a number of writings and initiatives ${ }^{2}$ have tried to gage and critically assess the potentials of contemporary (visual) art - anthropology collaborations. The trope of 'dialogue', of course, has been a much discussed term in anthropology (e.g. Tedlock, 1983, Tedlock/ Mannheim 1995, Maranhão 1990, Crapanzano 2004, Maranhão/Streck 2003), and despite different emphases it is clear that it can never just mean a level position of partners, collaborators, or actors, but has to account for difference.

2 This essay, then, explores the critical implications and potential of dialogical artanthropology collaborations, which are not set up in the closed 'laboratory' of a university workshop, ${ }^{3}$ but use the seemingly more 'open' ethnographic fieldwork situation as their locale. Moreover, they are also set in what characterizes many fieldwork situations outside so-called 'First World' countries, that is unequal relations of real differences in economic power, as well as access to educational and other symbolic capital (such as the hegemonic first world education system, and the equally hierarchically structured international art world). Practiced by somebody who is based at metropolitan first world institutions, this kind of anthropology, inevitably, is admittedly a hegemonic practice, whilst at the same time there exists of course, as in other Latin American countries, a specific Argentine anthropological research tradition which has to be accounted for (and is itself marked by the complex challenges of doing research and fieldwork throughout the country's troubled economic and political history, for which Guber 2002). 
The material for this essay comes from my own fieldwork collaboration with contemporary artists in Corrientes, North-East Argentina, over the course of two summers in 2005 and 2006. By contemporary artists, I mean practitioners in a variety of visual media (such as painting, sculpture, photography, film/video, mixed media), who have trained at art school, and exhibit their work in art world institutions such as fine art museums and galleries (in contrast to artisans who work for sale in the tourist market). ${ }^{4}$ In 2005 Mati Obregón, Richard Ortiz and Hada Irastorza participated, and in 2006 the team consisted of and Hada Irastorza and Pablo Macías. The principal objective of this project was to explore the epistemological implications and pragmatics of collaboration between anthropology and contemporary art in an ethnographic fieldwork project.

Extending on previous fieldwork with and among artists in Latin America (Schneider $2000,2004)$, the project also investigated 'appropriation', i.e. practices by which artists take symbols, artefacts, out of their 'original' cultural context to construct new identities with their artworks. ${ }^{5}$ The particular focus of the research was the village of Santa Ana, where I was based, and which was visited by the artists from the provincial capital Corrientes on several field visits. We were primarily interested in practices of popular religion, such as the celebrations of the Day of the Patron Saint, Santa Ana (on which more further on).

\section{The setting: provincial capital and village}

5 The principal site of fieldwork, Santa Ana, or Santa Ana de los indios Guácaras ${ }^{6}$, is a village about $15 \mathrm{kms}$. from Corrientes, the capital city of the homonymous province in the North-East of Argentina on the Paraná River, near the Paraguayan border. Both city and province are perhaps best known in the English speaking world as the setting of the Honorary Consul by Graham Greene, a novel about kidnapping the English honorary consul by left-wing guerrillas in the 1970s. Within Argentina, Corrientes is still regarded as a sleepy and poor outpost on the Paraguayan border, allegedly lacking the entrepreneurial spirit of the provinces of Misiones and Chaco, neighbouring it to the East and West. Compared with other parts of Argentina, Corrientes attracts few international or even Argentine tourists. The exception to this pattern are perhaps the extensive wetlands, lagoons and lakes comprising the Esteros de Iberá in the centre of the province, which over the last years have seen an increasing number of visitors. ${ }^{7}$

6 The village of Santa Ana, then, presents itself as a village of 'tradition', where 'it's possible to hold peace and tranquillity in your hands', as advertised on promotional websites. Most buildings are low one-storey houses. The roads are deliberately left unpaved and covered with sand, which gets renewed and cleaned by the department of municipal works. ${ }^{8}$ 
The statue of Santa Ana on the Day of the Procession, July 2005.

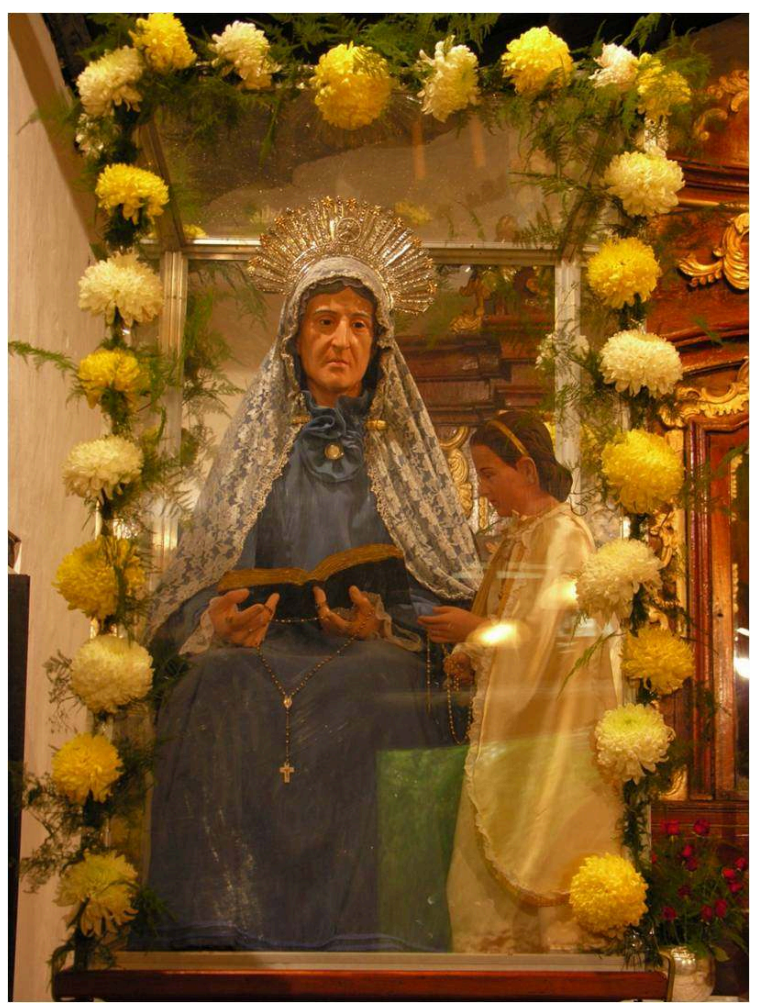

7 Photo Arnd Schneider

The statue of Santa Ana during the Procession, led by Padre Epifanio, July 2005.

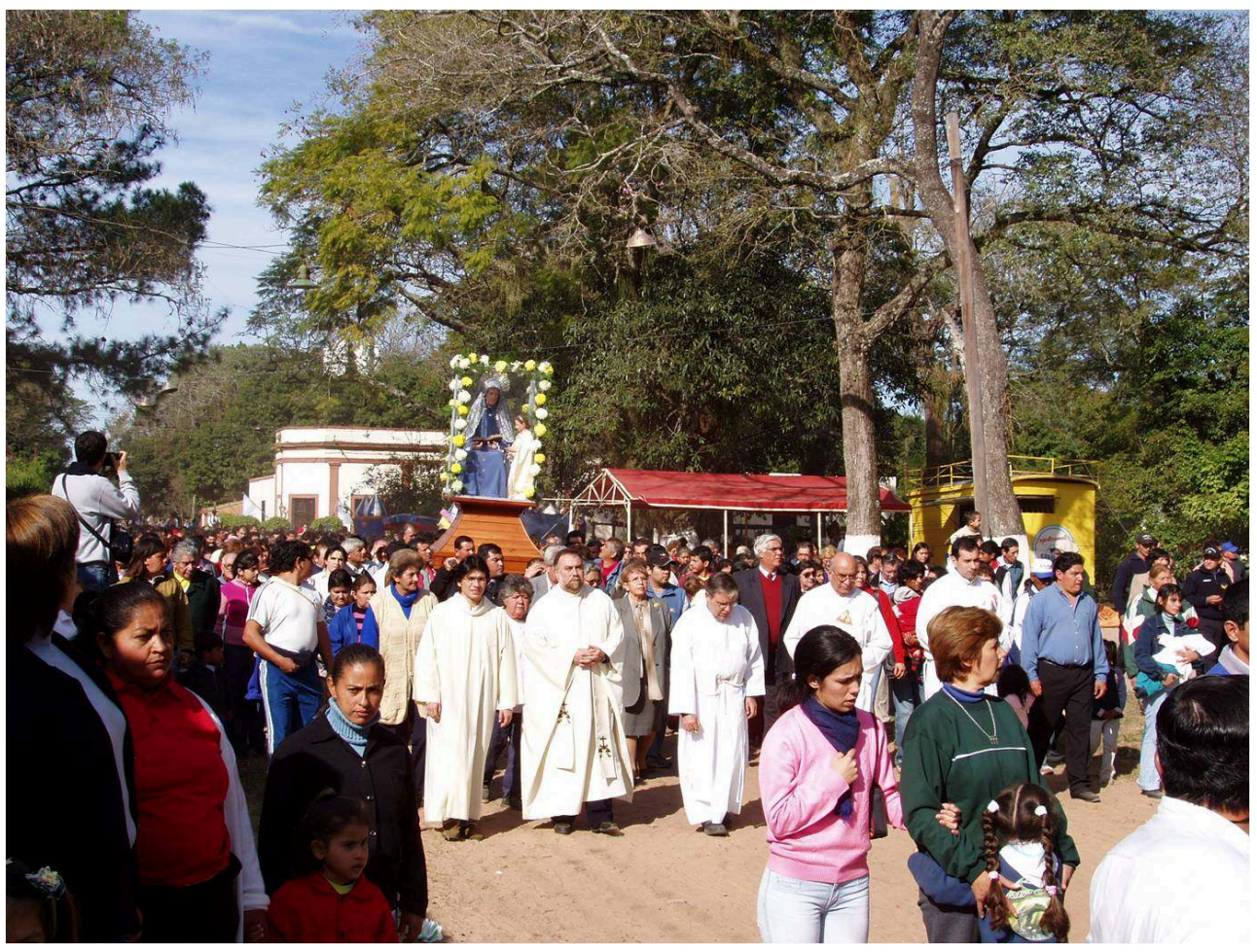

Photo Arnd Schneider 

village territory. The vegetation is rich and sub-tropical, with the foliage of the huge mango trees providing shade, as well as banana, papaya (mamón), orange, grapefruit, and lemon trees.

In 2006, about 3000 people lived in Santa Ana - 2941 according to the census of 2001 (Muncipio de Santa Ana, Registry Office 2001). Employment in Santa Ana is precarious, most people work as cleaners, domestic servants, security personnel, policemen, guardsmen and soldiers in Corrientes, whilst a few jobs exist in the public administration of Santa Ana (usually given through patronage in return for political favours), as well as part-time work in attending to the larger houses and estates which wealthy Correntinos have built in the small village. This sporadic work is known as changa. Occasional work might also arise through public building projects, road building and maintenance, and implementation of electrical lines and mobile phone networks by private companies.

10 A few families and individuals from Santa Ana have become long-distance migrants beyond Corrientes province, and settled in Greater Buenos Aires, and in one case even in Spain, for better work opportunities.

11 Most families have also some access to agricultural land, either on the plots they inhabit in the village, or in the fields surrounding the village. Many families also own a few horses, and some cattle (and also work for others who have cattle). However, large tracts of land outside the village, and stretching towards the Ingenio "Primer Correntino" (or San Joaquín) settlement, are owned by large landowners. In 2006 there were a handful of small commercial agricultural enterprises on the village's territory, including a poultry and rabbit farm, and a strawberry, pepper and tomato farm run by a Japanese immigrant as well as four other establishments, producing poultry, rabbits, garden plants, manioc and sweet potatoes. In addition, there were eight registered artisans, producing mate gourds and accessories, knives, candles, leather goods, and jams and preserves. ${ }^{9}$

12 Till the early 1960s, the local economy was sustained by a sugar mill (ingenio) in the Ingenio "Primer Correntino" about $5 \mathrm{kms}$ by dirt road from Santa Ana. Sugar production, after the foundation of a sugar mill in 1882, had its heyday at the end of the $19^{\text {th }}$ and the beginning of the $20^{\text {th }}$ century, with a narrow gauge train line ${ }^{10}$ to bring workers, (and transport cane and refined sugar and sugar products), from Corrientes to Santa Ana (and beyond). ${ }^{11}$ In the 1950s, sugar production diminished significantly and the factory finally closed in 1965 (Cocco 2004b: 27-32). Land was distributed by the government to local people, as well as French pieds-noir immigrants, white settlers from Algeria, coming to Argentina on a government sponsored scheme after the end of the Algerian war in 1961/62. Since then the buildings and former rail yard have become completely derelict, with local people using parts of the building for squatting and building materials, and vegetation claiming back the rest.

13 In the narratives of older people the ingenio is invariably mentioned in connection with an earlier period of significant wealth for the area, providing work and income for many. Only occasionally, reference is made to the hard labour the sugar mill entailed. ${ }^{12}$ In the present then, the ingenio, is a buried memory, literally half swallowed up, by the sub-tropical vegetation. 


\section{The festival of the Patron Saint}

All towns and villages in Corrientes, as in Argentina, and much of Catholic Latin America (in fact the Catholic world), have a Patron Saint, whose particular day in the religious calendar is often celebrated with a procession and other festivities (see also, Graziano 2006). Santa Ana celebrates its patron Saint, St. Anne, the mother of St. Mary, Jesus' mother, on 26 July. The celebration is staged as two closely related events. For in fact the actual Saint's Day (which often falls on a weekday) is either preceded on the previous Sunday or repeated on the following Sunday by an extra celebration, to allow pilgrims and tourists to join the celebrations. Both celebrations culminate in a procession with a statue of Santa Ana, which starts from the church and then proceeds one block further from the church square, in a rectangular closed circuit, re-entering the churchyard at the end, where an open-air mass is held. The celebrations are preceded by ten days of daily spiritual exercises, including the reciting of the rosary, the novena, and masses, in which different sections of the population, municipal employees and schools participate.

\section{A shrine dedicated to the popular saint Gauchito Gil, Santa Ana.}

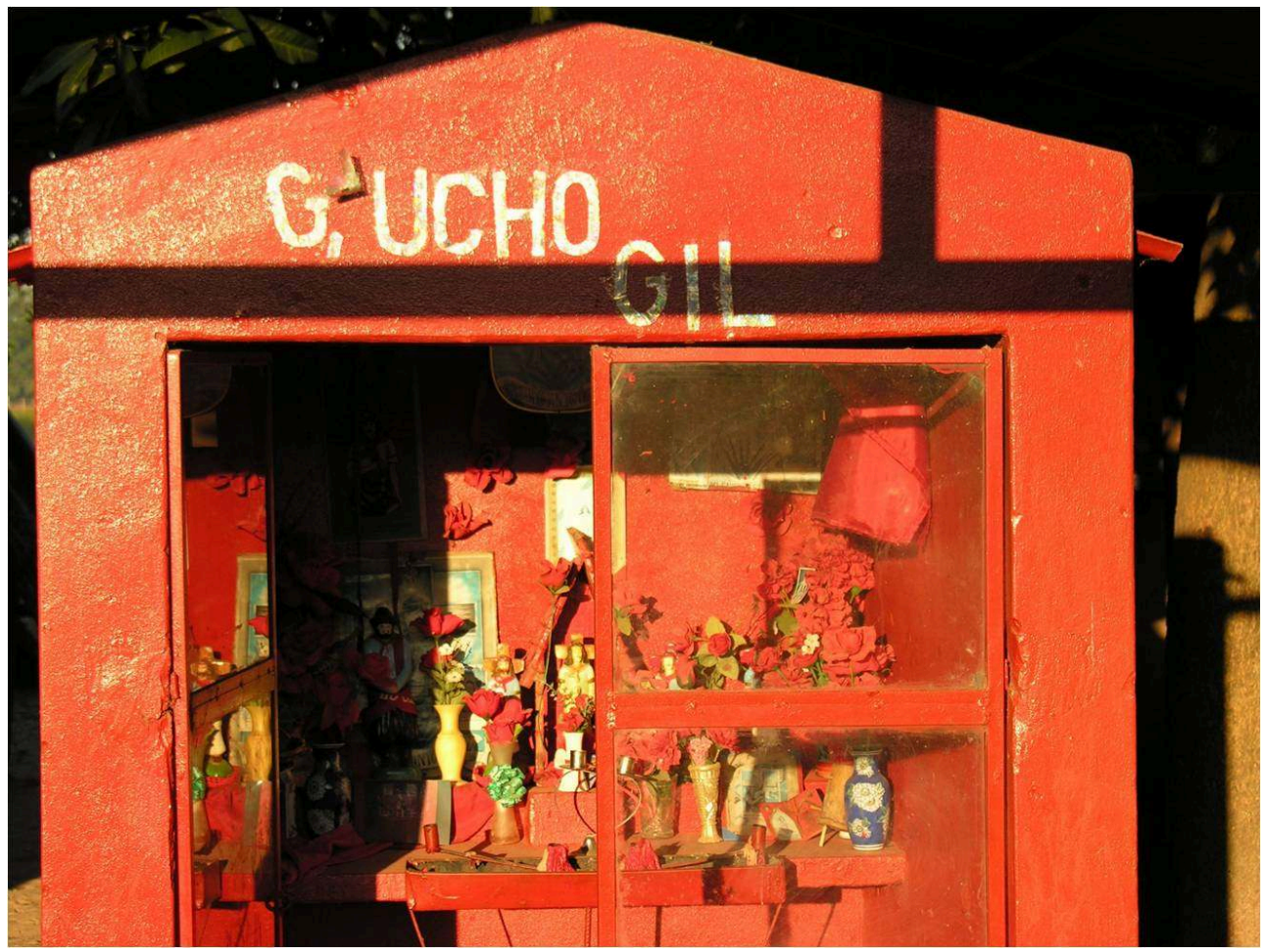

Photo Arnd Schneider 
Installation "Santa Ana - una aproximación artistica-antropológica" (grid plan of Santa Ana), Mati Obregón, Richard de Itatí (Ricardo Ortiz), Arnd Schneider, Museo Provincial de Bellas Artes “Dr. Juan Ramón Vidal", Corrientes, 19 August 2005.

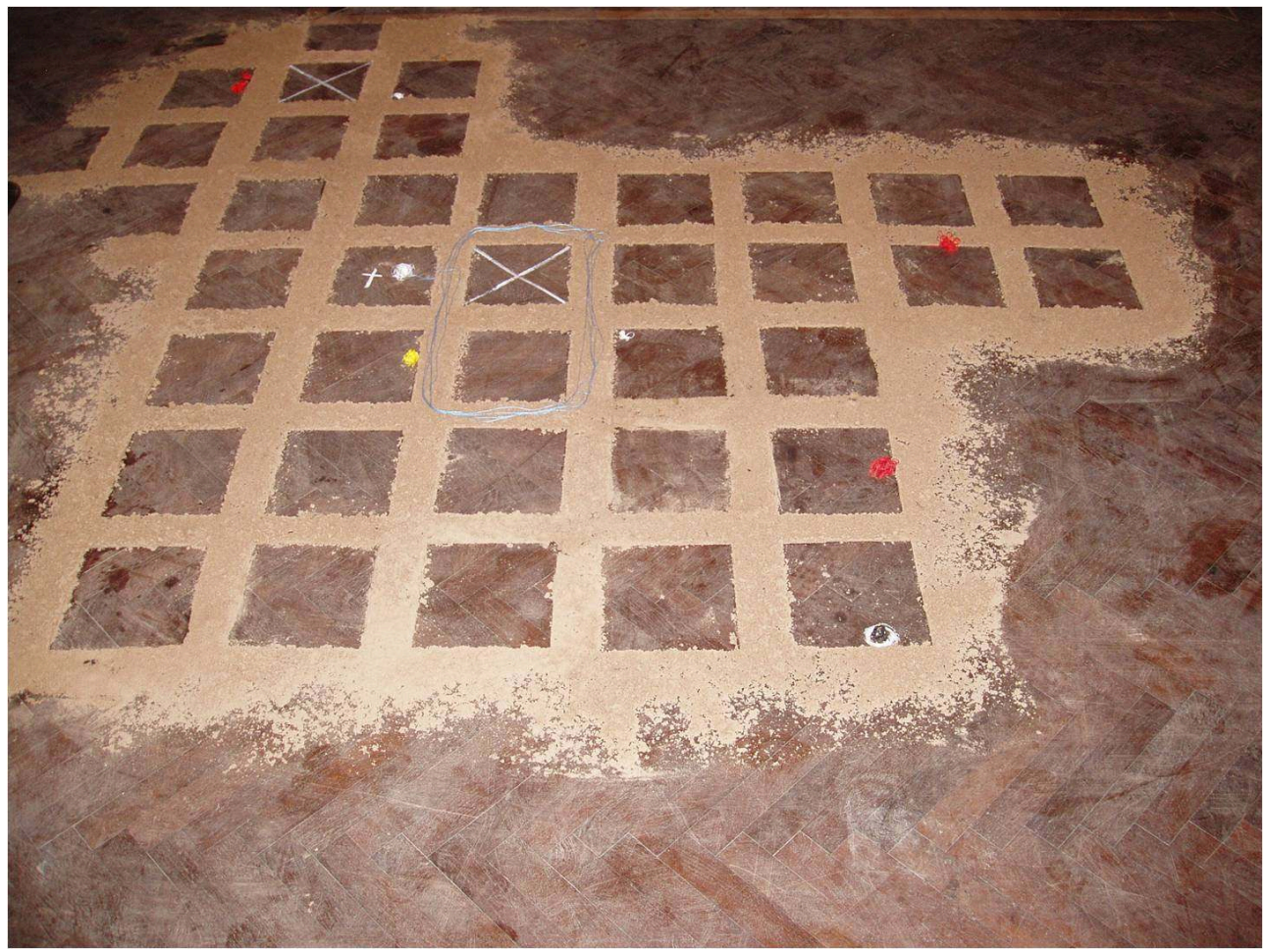

Photo Arnd Schneider

The statue of Santa Ana with her new dress and embroidery by Hada Irastorza during the Procession, July 2006.

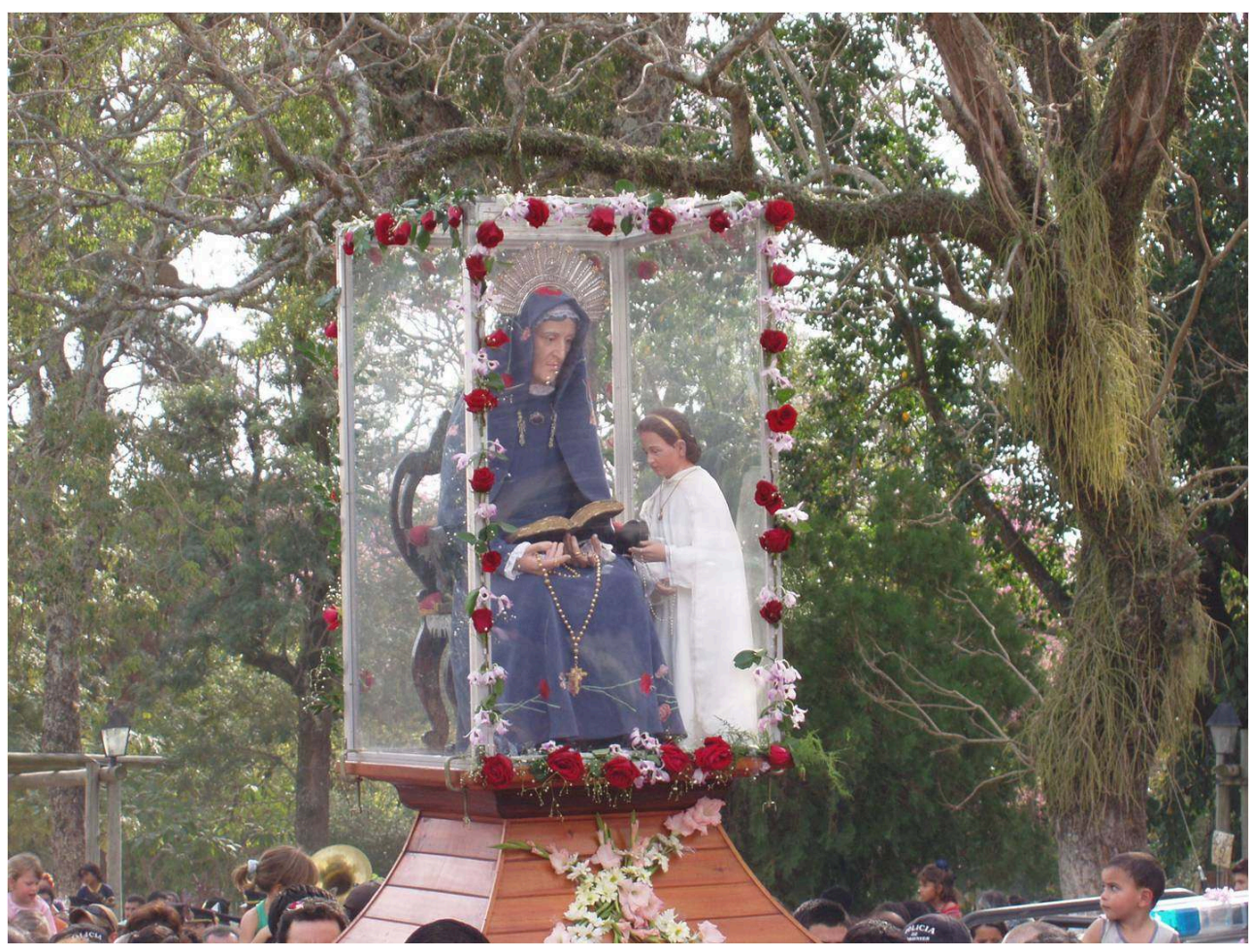

Photo Arnd Schneider 

riders and carts (when used), followed (in 2006) by a display of riders' virtuosity and bravura, such as in the game known as the carrera a sortija ('race for the ring'), held on the side of the square opposite of the church. For this game, a line is hung across the road with a small ring suspended from it which riders in full gallop have to hit with a small pin - an extremely difficult task as the rope keeps moving in the air with the ring is turning - in fact, the challenge is only mastered by the ablest of riders.

\section{The Challenges of Collaborations: Auto-Ethnography, Material Participation and Uneven Hermeneutics}

19 It was this setting of popular religiosity into which our research team intervened through participant observation (or rather material participation) interviews with villagers, and the eventual production of artworks presented at the provincial art museum in Corrientes, with an installation in 2005 and the display of sketchbooks and a film in 2006.

We were not the only ones in the business of producing and projecting visual imagery in the context of the procession. During the celebrations for Santa Ana in 2006, employees from the village had put up a computer and beamer to project images onto the village square, which showed images of the statue of the patron saint Santa Ana, as

Les actes de colloques du musée du quai Branly Jacques Chirac, 2 | 2009 
well as from past fiestas de la tradición and a variety of shots from the village of Santa Ana. The selection of the images was clearly indicative of how villagers wanted to represent themselves, what they perceived as typical, and what kind of image of image they wanted to project to the outside world. The religious festivities, combined with the traditional aspects of rural customs (a specific type of gaucho culture) occupied the central position in this municipal slide show on the square as in other promotional material by the municipality, ${ }^{16}$ and was accompanied by images from the 'colonial' village, 'preserved' for pilgrims and tourists.

It was clear from how villagers in this context were presenting themselves that a central narrative of identity for the village is woven around the preservation of the image of the colonial traditional village and gaucho customs, and the yearly fiesta to honour the patron saint, Santa Ana. To focus on exactly these elements for our research and anthropological and artistic representation then seemed very legitimate, and was fully accepted and supported by the villagers we interacted with and interviewed.

The main challenge in this project consisted of bringing together visual artists and an anthropologist with very different backgrounds and expectations in a collaborative research project. This has been done occasionally in Western academia and contemporary art, ${ }^{17}$ as well as in Latin America. ${ }^{18}$ However, in the Argentine context, and especially in the province of Corrientes, this approach represented a certain novelty. ${ }^{19}$ One of the most difficult and complex challenges consisted in achieving an understanding of the specific notions of art, and indeed anthropology held by the participants, and vice versa to familiarise the artists with the ethnographic method, and more generally, with the disciplinary scope of anthropology. The result was a continuous process of two-way conceptual, yet uneven translation. Regular joint discussions between the project participants revealed fragmentary, and contested notions of each other's practices, yet in a gradual process both sides learned from each other, to achieve a complementary understanding.

The project clearly showed differences in the understanding of fieldwork and anthropology. For the artists, similar to anthropologists who do "anthropology at home", the excursions to Santa Ana, were trips to home territory, and at the same time "exotic", as the village represents the rural "other" to city dwellers. On the other hand, the cultural embedding of artists also reflected upon the fieldwork, and enriched the process of learning and eventual understanding for the anthropologist.

From the view point of the anthropologist, artists' approaches seemed more sporadic and ad hoc, when compared to certain types systematic ethnographic data gathering. I emphasise 'certain types' here, as much of ethnography is now not only multi-sited, but also fragmented in multiple diachronic time-sets, which do not necessarily co-incide, when one thinks about recent ethnographic research on and with the internet, mobile electronic devices, and virtual realities. ${ }^{20}$

However, the conceptual differences in our fieldwork project engendered a productive dialogue, some of which was recorded as joint discussions. Together with other data, such as the anthropologist's field diary, as well as the material forms of representation produced in the fieldwork process (artworks), these discussions formed the basis for further analysis and interpretation.

Thus the project was characterized by a continuous process finding 'common' terms of communication or making different terms mutually comprehending, which involved 
constant negotiation for a shared way of understanding. In these discussions the artists contested the anthropological project, and also claimed local reality as theirs (especially notions of popular religion, and the sacred). They increasingly perceived their own participation in the project to be a process of 'auto-ethnography', or in even more corporeal terms as 'auto-vivisection'. In a reflexive way they went in fact beyond what in another context Lorenzo Brutti (2008: 289 -90) recently called 'native autoethnographies', or 'vernacular auto-ethnographies'.

These reflective preoccupations are clearly brought to the fore in the conversations I had with Mati Obregón and Richard Ortíz, the two artists who collaborated in the first phase of the project in 2005. We were discussing here the possibility of showing our work in the provincial Art Museum, possibly by bringing sand from the village of Santa Ana, reflecting its peculiar feature of leaving roads deliberately unpaved, but having them filled with sand, in order to preserve the image of a traditional village, wanting to attract tourists.

Mati Obregón: To take sand seems more like a game, but I don't want to play now. It seems more serious to me to make a PowerPoint presentation and that we talk, rather than to make a show. Were you thinking the same?

Richard Ortíz: No, I rather thought something else. But it's something personal. This work is a bit like taking advantage of, or exploiting, what I have already incorporated.

Mati: A bit like an 'auto-vivisection'. I am not taking advantage of, or exploiting, what I have, I use it.

Richard: The image, the lived experience. To make an artwork about the procession gives me the impression that I am taking advantage of it.

Mati: I think for us this continues to be something sacred.

Richard: That's what's happening.

Mati: Because for me the procession, on the one hand, is something completely rational as for any other educated person. However, on the other hand, there is also a part in my being which I regard as very sacred. For instance, I don't omit making the sign of the cross when I enter a church. I do it sometimes even out of respect for the persons who are there. It's a very sacred space, and it's a very fine limit between the sacred place, the other, and myself, when I take part in this procession.

Richard: It's like putting these very sacred things, which we have lived with since we had consciousness, and then suddenly to transfer them to the art world.

Arnd: But exactly this happened in the recent exhibition on the Gauchito Gil21, yet it was done with a lot of respect towards the beliefs.

Mati: I know, but personally, I am not sure if the exhibition on the topic of the Gauchito Gil was the right thing. I took part in it, because this is my work, and I presented my work in the show, because there was money which I would earn in this competition. But I thought a thousand times, how to expose my belief and in some ways, to re-signify the image of the Gauchito Gil. But what does it mean, after all, to re-signify the image? This image exists already, and we have it in popular culture, and there is no other. Time already made this image, and it will not leave my brain - this is the image for me. To re-signify the image is to make the sacred banal - I don't need another image of the Gauchito Gil. It's this little part of magic which I think still exists here and which makes 
me part of this place. I understand Richard. I, too, play with the image of the Virgin, but there is always this limit [of the sacred]. 

without aestheticizing, or putting things which just adorn without effect? But instead, it should provide the most crude and most precise information for the rest of the world.

Arnd: Some key objects, perhaps.

Richard: I thought that maybe it is not necessary to take so much earth. We can take a little bit and make some pathways.

Arnd: Or to make a map, the central part of the grid plan of the village.

Mati: Or the circuit of the procession.

Richard: I like the idea of the vehicles and carts which leave tracks in the sand, and then the steps of people leave almost little mountain ranges.

Mati: But we haven't got the material to leave these tracks.

Richard: But didn't we say we bring a lot of sand to fill the surface of the room?

Mati: That would be an exaggeration.

Richard: So, we have to do something more subtle.

Mati: I like the idea of the map.

For the presentation of our project at the Provincial Art Museum, we agreed on the map, and we used sand to lay out a grid plan of the central part of Santa Ana with sand (brought form Santa Ana) on the floor of one of the museum rooms, and marked the route of the procession with white thread; other instances of popular religion were marked in different colours. The other part of the installation consisted of three black pedestals on which we placed traditional breads from Santa Ana, and a large paella pan (used for communal activities, such as election parties) placed in front of it.

About 30 people attended our presentation which included PowerPoint with pictures from our research. I first presented the background of the project of the notion of fieldwork in anthropology and collaboration with the arts, and then the artists spoke.

Mati: First of all, I found myself observed like a strange being. I felt they were to take my soul, as the people must have felt whom Arnd approached to record, and sometimes did not want to. At one stage, I said I will do this and I could make any artwork from this, but I felt observed and that I was delivering my most private secrets. This I didn't like - I don't know about Richard...

Richard: What happens with this project is that he [Arnd] wants that we put in all our experiences which we had and to do it quickly from one day to the next it's something a bit forced, a mere illustration. This is one of my preoccupations when making contemporary art.

7 Mati: So for me to make a work of art about Santa Ana to show it to somebody, for me it's like an aberration. Not knowing what to do, I started collecting things in the fiesta. I collected the little medals they sell in the plaza. I started to work like an anthropologists. I can tell him the story of my life, my feelings, but he didn't come to look for this.

68 Richard: I think he looked for us like some translators.

Mati: This is what we were. We were like a tube or channel, because he wanted to know, not speaking the local dialect, and some 83 year old women might not understand him. 

there are things which I do not want people to know. There are things I do not want people to know, because I they will not understand it. My beliefs they will not understand, the saints full of rugs and attached hangings, they will need years to understand, I don't yet understand them, and I am from here. So there are things they will understand, and things they won't. Through the project I also made some autoethnography, I studied myself once more, and that helped me also to look inside, to look at me. longing. That is like an objective gaze, from afar, and so now we make this autoethnography and Arnd gives us the theoretical support. We also helped him a lot, because there were things he might not have noticed otherwise - so we helped each other.

So what I had conceived of as a project of exploring different forms of research and representation in contemporary art and anthropology, turned out to be, at least in part, to be process of artists doubling as anthropologists, entering a process of autoethnography, problematizing their identity, and contesting the anthropological project more generally (as they experienced it), and our project in particular. The project thus engendered a process of self-reflection, auto-ethnography and self-criticism for both sides. Of course, in more classical anthropological terms, the artists were not strictly from the village of Santa Ana, but nevertheless from the region, and thus part of a cultural continuum, and very familiar with the cultural specifics of the village, even if there was some variation.

The contestation of the anthropological project and the strong reflective criticism, however, did not lead to a discontinuation of the project, but rather resulted in a selfreflective and productive co-operation which culminated in the installation and presentation at the museum, which is also how the criticism of the project was brought into the public sphere, and became part of the project itself.

In the public discussion after the presentation the charge of exoticism was also brought up, of why we had chosen Santa Ana which was, after all, a folkloric tourist village. The question had been posed by a natural scientist form the Universidad del Nordeste (the local university), who also held a rather evolutionary view of modernization. For instance, he took London (my academic base at the time) as the high point of modernity, and was rather surprised when I had to tell him that the London Underground was anything but modern, and London, at the same time as being a financial world centre (and thus being at the apex in the international division of labour and capital), was also a city displaying huge internal social and economic differences. We then concluded the discussion by agreeing that different levels of modernity, especially but not exclusively in Latin America, could co-exist.

What the artists described in their words as 'taking advantage of or 'exploiting' from the local reality can also be understood as a more general process of cultural appropriation, in this case in a broad regional sense from the artists' own culture from which they were reluctant to concede information, or to fully engage with. This was despite the fact that some artists, such as Mati Obregón had already employed strategies of appropriation in their previous work, albeit reluctantly (as shown in her example of the Gauchito Gil in the discussion extract). The project resulted for the artists in a complex and contradictory process about the revelation of content, or 
release of meaning, and negotiating it as translators or conductors of meaning with the anthropologist, who in turn was another translator of meaning to construct understanding. It is noteworthy that the notion of auto-ethnography (though actually present in my research proposal) emerged from our discussion, but was less present during the actual fieldwork sessions with interview subjects from the village.

One fundamental difference, when compared to similar projects in richer countries, consisted in the huge economic disparity between the anthropologists and the artist (comparable to that existing between anthropologist and interview subjects, i.e. the villagers). The artists I was co-operating with had no or only small fixed sources of income. In 2005 Mati Obregón was employed part-time by the provincial art museum, and Ricardo Ortiz was still in art school. In 2006 Hada Irastorza and Pablo Macías were hired part-time as cultural workers by the Department of Culture of the city of Corrientes, which provided a very modest, but regular salary.

The precarious economic situation impacted on the work, as I was effectively asking the artists for free labour on the project (they could have used the time to engage in some paid work, or preparing for art competition were prizes were awarded, and sometimes a small some of money, but which in any case gave credit to their CV and portfolio). However, I decided not to pay wages or a fee, but rather subsistence (travel from Corrientes), and for food and drinks during our trips. There is no custom to pay artists free-lance, and some people form Corrientes art-world advised against it, as would have corrupted the project, and work, real input, and time, were difficult to measure. There was no contention by the artists in my proposal to ask for their free contribution, but to help them to achieve an exhibition in Corrientes, and possibly elsewhere. ${ }^{23}$ Yet during the project I sometimes realized the difficult economic situation, for instance when we could not communicate by mobile phone because one or the other artist had run out of credit.

\section{Participant Observation as Material Participation}

Whereas I had expectations of the artists engaging in quasi anthropological fieldwork, encouraged them to take a sketchbook, and collect things during the field trip - for them, with the exception of Hada Irastorza (the main participant in the second phase of the project), this kind of anthropological fieldwork methodology remained something alien and artificially imported by somebody outside of the artworld, as expressed in the discussion extracts.

For the artists, what counted in their careers was to have approval and acceptance by the local, and possibly national art world, and this meant to take part in competitions (concursos), win prizes (being nominated, with or without prize money), and show in prestigious places of the hierarchically structured art world. Another reason for artists not using more ethnographically inflected approaches might also be that these are not emphasised by the local art school, nor is site specific work (whereas installation is).

\section{Material Participation}

In the second phase of the project in 2006 I worked with Hada Irastorza, a visual artist, and Pablo Macías, a video artist and film-maker. ${ }^{24}$ Hada had already participated 
towards the end of the 2005 phase, when she decided to get more involved and make a new dress for Santa Ana. During the intervening year she made regular visits to Santa Ana, saw the parish priest Father Epifanio, as well the committee who arrange the festivities for Santa Ana, and got their permission to make a new dress. Through Hada it was also possible to get more insight into the actual significance of dressing Santa Ana, an event in which only four selected women and the priest can participate. The dressing of the saint's statue lasts twenty-five minutes and five rosaries are recited as part of the closed ceremony.

81 Hada Irastorza's artwork constituted a continuous process of immersion into the local reality, marked by repeated visits, culminating in the use of the dress in the procession. Participant observation thus became material participation and the dress as artwork was incorporated into the observed reality, and assumed also social agency in the procession (in that it was the visible sign of artistic participation and intervention, and also elicited comments from the villagers). It also became the material sign, so to speak, of the artist's intervention, and in larger sense, the projects' intervention into the social life of the community. It thus 'materialized' anthropology's and art's agency in this project. The people of Santa Ana accompanied very positively this act of artistic intervention into their procession. In this sense, an outsider artist (for instance a western artist working with me, the Western anthropologist) would have had much more difficulty in gaining the trust of the faithful and the council organizing Santa Ana's fiesta. Hada was definitely advantaged in gaining the trust, and establishing a productive relationship.

Hada also came to Santa Ana to participate in a number of fieldtrips and as an able draughtswomen felt most at ease with the artist sketchbook, whereas Pablo freely admitted that, as a film-maker, this was not his chosen medium. Hada was the artist most at ease with the ethnographic approach, and to some degree made it her own. Thus in terms of which artistic genre to work in and what kind of media to chose a careful negotiation had to take place which had to take into account artists' inclinations and preferences, as well as locally available artistic materials.

\section{An Uneven Hermeneutic Field}

Arguably, anthropologist and artists found themselves in what can be described as an uneven hermeneutic field. Uneven, in terms of the access to economic capital, but also uneven in terms of local and regional knowledge, which the artists possessed.

In terms of if the hermeneutics of fieldwork and representation, the cultural embedding of the artists enhanced the understanding of cultural expressions specific to the region, such as chamamé music, or the symbolism surrounding popular saints, such as the Gauchito Gil or San La Muerte. The co-operation with the artists, specifically in regard to artistic transformation of fieldwork into materially manifest instances of representation (artworks), yielded data different to that of text-based audio recordings, and stills photography.

One of the aims of the research was to explore, in the practical terms of a fieldwork situation, the limits and possibilities of perception and representation among collaborating artists and an anthropologist. Put more crudely, of how artistic practice can extend anthropological knowledge, and vice versa? 

compared to those I and my peers in visual anthropology (and perhaps also contemporary artists) are accustomed to is provided by Pablo Macías' contribution, the video artist collaborating on the project in 2006.

91 Pablo accompanied Hada and me on the two fiestas for Santa Ana in July 2006 (see above), where he shot with the help of another cameraman a considerable amount of footage. He later edited the footage into two three-minute sequences for a simultaneous double projection at our presentation at the end of the project (Registro Audiovisual /sin título). The sequences, combining various shots from the fiesta, were edited in a very fast style to a precise soundtrack of chamamé music, a popular music genre common in North East Argentina, Paraguay and Southern Brazil. chamamé music was a secure way of winning most people's consent in Corrientes. They had perhaps not noticed that apart from the surface appearance of the work as both depicting and playing to popular folkloric tastes, and Pablo also intended the film to carry a critical message. In fact one of three-minute sequences showed the priests officiating during the mass, sometimes in revealing close-up, and the soundtrack repeated parts of the mass, closing with a resounding 'Amen'. Whilst this work can be read in many ways, and respected overall the religious background of the fiesta, it also contained, as Pablo told me, a veiled critical message, in that it was suspicious of the Church's appropriation of popular religiosity.

However, when I showed the sequence in my Summer School of Contemporary Art and Anthropology in 2007 the reaction was one of perplexity. Some of the participants protested that this was not visual anthropology, but some folkloric promotional video. of course, those who reacted in this way, trained to narrative styles of long takes in the observational kind of documentary cinema, had no knowledge of the cultural 
background of Corrientes and its strong popular Catholicism, the status of chamamé music, and could not understand or appreciate the subtle criticism voiced by the filmmaker.

Whilst one can argue with the aesthetics of this film, its brevity and abrupt montage, where images are cut to a specific and precise soundtrack of chamamé music, the question remains, 'from which vantage point such a critique is to be voiced?' Are we to apply criteria of Western art schools and art criticism? And, further, which Western viewpoint will be privileged?

Perhaps this tells us more about the hegemony of western critical knowledge (here as modes of visual production) and its short circuited consumption than about the specific cultural framing by the film-maker.

The installation of a grid plan, traditional bread loafs from the village, and the exhibition of a paella pan helped to visualise the procession and made visually and materially manifest the fieldwork process, and similarly went beyond established patterns of representation in anthropology.

\section{Challenging borders between sacred and profane}

\section{(NOT PRESENTED AT THE CONFERENCE)}

Another of the issues highlighted by the artists, as can be discerned from the above conversation extracts, was the transfer, in terms of their artistic practice, across perceived categorical boundaries of the secular-profane sphere (i.e. the Corrientes artworld) to the religious-sacred (i.e. the religious practices, both Catholic and those of popular religiosity), and vice versa. It was clear that these transgressions of realms of different categorical (and perhaps also ontological) orders, related to something very personal and private to the artists. For instance, in Richard Ortiz's family home in Itatí there is a small house shrine with images and small statues of the Virgin of Itatí and other saints. Matí Obregón also declared that her religious beliefs were something very personal which she did not want to reveal easily. Somehow, through the research process, she felt exposed of her inner self (although this was not clear to me during the research, but only came out in the discussions). She even maintained this sense of uneasiness when asked about her participation in the show on the Gauchito Gil, which apparently she did only reluctantly.

9 Other Argentine artists, have addressed explicitly the transgression of sacred and profane spheres and their principal interchangeability head on. Most prominently this topic has been worked on by Alfredo Portillos. Portillos, who during his exile in Brazil in the 1970s became a member of a Candomblé cult, has since made a number of works challenging the sacred/profane divide, and incorporated spiritual and magical experiences with the 'other'. ${ }^{25}$ Alfredo Portillos, as other Latin American artists, such as Cubans José Bedia and Ana Mendieta with their engagement with Santería and other magic practices, transform spaces of the art world (museums, galleries) into ritual or religious spaces, pointing both to the inherently religious character of these spaces (or 'temples') in a secularised society, and to the porous borders between some artistic and religious practices. ${ }^{26}$ rites.In his installation Ecumenical Space $(1977,1994),{ }^{27}$ Portillos used art gallery space 
to have religious rites by various religious denominations (Buddhist, Jewish, Candomblé, Christian) performed in sequence, and with an open invitation to the public to participate.

101 Another example is Hugo Vidal's Procesos en Procesión (1994), an exhibition and video on San Cayetano (the patron saint of workers in Argentina). Vidal bought a statue of the saint in a shop for religious devotional paraphernalia and added a simple dish as a halo. Originally, Vidal conceived of an installation pieces with broken dishes, signifying hunger and desperation of Argentina's poor, in a country which still is a major agricultural exporter, but once was also the eighth-richest country in the world. Vidal then exhibited the statue in the municipal art gallery of Buenos Aires, the the Recoleta Cultural Centre. Thus in the first instance a saintly statue was purchased, a dish added as halo, and transformed into an object of art and shown in a space dedicated to and defined by contemporary art. In a second step the statue was then taken from the exhibition and carried by Vidal on the Procession for San Cayetano on 7 August 1994, thereby reinserting it into the religious context, although it changed its appearance, and arguably also its context (as it had been shown as an art object already). Taking a religious statue from a modern art gallery exhibition and re-inserting into a religious procession, signifies almost the reverse process when compared to Espacio Ecuménico by Alfredo Portillos, where an art space is used for the performances of religious ceremonies. As Hugo Vidal mentioned in our interview, ${ }^{28}$ when walking with the devotees of San Cayetano during the processing, it was curious that people would accept the statue, expressing their reverence by making devotional gestures (such as touching and kissing it). They commented on the beauty of the statue (which was slightly larger and better manufactured than their own more modest ones). But intriguingly, the plate which had been used instead of the original halo - a clear artistic intervention - did not provoke comment.

102 However, in the context of Corrientes the spaces of the sacred and the profane are less separated (indeed, they are more interrelated) and religious practices occupy a much larger role and have a higher status in the public sphere than is generally the case in Buenos Aires.

\section{Conclusions}

103 It becomes clear from the material discussed in this essay that there can be no normative a priori demands when collaborating with artists. This is especially the case, as in this project, when the planned collaborations are between project partners with widely different educational, cultural and economic backgrounds, which also result in different expectations for the outcome.

104 It is only through a procedure of mutual respect and understanding that a hermeneutic field, however tenuous and uneven, can be achieved, which can be the basis of future collaborations.

105 In this context, it is fruitful to think of Kester's discussion of 'dialogical aesthetics' (Kester 2004: 82 -123). Kester develops the concept in relation to a range of art practices which develop, or are based on, social relations with communities and individuals, even if these relations, established by artists are temporal. Some of these practices can be called community art, others have been signified as 'relational aesthetics' (Bourriaud 2002), when artists themselves instantiate social relations as artworks. Kester offers an 
interesting discussion of the possibilities of dialogue between artists and 'communities' which through the artworks they both socially relate to and create. He builds on and at the same time departs from Habermas' notion of the 'ideal speech act', which can only remain a philosophical postulate, or ideal, proposing equal and 'ontologically stable' partners - a condition which is not realistic when participants in dialogue have different access to power, educational and cultural capital. Kester (2004: 106) suggests, following philosopher Fiumara (1999), that any dialogue has to start not from a position of presumed equality, but with an act of self-reflective listening, interrogating the 'ethics of communicative exchange' (2004: 106). This line of thinking comes close to Trinh T. Minh -Ha's concept of 'speaking nearby', said otherwise, that in ethnographic representations we cannot speak about or for the other (and that any attempts to lend the other a voice remain illusionary, as early textual critics assumed), but at best can speak nearby (T. Minh - Ha 1994).Inherent in any discussion of the ethics of such projects must be the recognition and self-reflection upon an unequal relationship, based on difference, between the partners in fieldwork (as recently argued by Benson / O'Neill 2006, taking inspiration from Levinas). This unequal relationship is expressed in terms of economics, as well as aesthetics - and also asks for acknowledgement, or rather hermeneutic tolerance for artistic works, such as Pablo Macías' video. I contend that it is this fundamental acknowledgement of dialogical inequality which constitutes an uneven hermeneutic field which can still render a productive collaboration. organized by Caterina Pasqualino and Arnd Schneider.

\section{ABSTRACTS}

Every year, the inhabitants of the Santa Ana village in Argentina celebrate their patron saint on July 26th. This project involved collaboration with contemporary visual artists from the nearby provincial capital, Corrientes, and the making of a series of hybrid 'works' between art and anthropology. This included material participation in (rather than "observation of") the performance of the procession, i.e. making a new dress for the saint's statue, producing a video, and field notes. The appropriation and material intervention into a setting of popular religiosity raise questions about the epistemological status of art and anthropology collaborations as hybrid knowledge productions.

Chaque année, les habitants du village de Sainte Ana en Argentine célèbrent leur saint patron. Fruit d'une collaboration entre l'auteur et des artistes de Corrientes, chef-lieu de région, ce projet est basé sur une série de travaux impliquant plusieurs modes de participation à la procession (plutôt qu'une " observation de »), qui vont de la production d'une vidéo et de prise de notes de terrain, à la conception d'un nouveau vêtement pour la statue du Saint. Produisant des connaissances hybrides, l'appropriation et l'intervention dans le cadre de la religion populaire soulèvent des questions sur le statut épistémologique des collaborations entre art et anthropologie. 


\section{AUTHOR}

\section{ARND SCHNEIDER}

Arnd Schneider est professeur au Département d'Anthropologie Sociale à l'Université d'Oslo. Il a obtenu son Ph.D. de LSE (1992), et l'habilitation de l'Université de Hambourg (2006). Parmi ses publications il y a Futures Lost: Nostalgia and Identity among Italian Immigrants in Argentina, (Berne/New York: Peter Lang); Appropriation as Practice: Art and Identity in Argentina, (New York: Palgrave, 2006), et Contemporary Art and Anthropology (co-edited with Christopher Wright; Berg, 2006). Il a co-dirigé Fieldworks: Dialogues between Art and Anthropology, à la Tate Modern, 2003, organisé the International Symposium, Art/Anthropology: Practices of Differences and Translation, au Museum of Cultural History, Oslo, 2007, et co-organisé l'exposition The World Kaleidoscope: Images and Objects from Fieldwork in Anthropological Research, à la Galleri Sverdrup and the Museum of Cultural History, University of Oslo, 2008. 